Adrian K. Ho and Daniel R. Lee

\title{
Recognizing opportunities
}

Conversational openings to promote positive

scholarly communication change

ibrarians in the midst of conversations With members of the campus community are often hesitant to bring up scholarly communication issues. Numerous online resources have been created in the past few years to help campuses address these issues, but some of us, whether or not we are familiar with these resources and are comfortable with the relevant concepts, aren't quite ready to talk about the resources and translate the concepts into practices. This article aims to provide scenarios of how such resources can come in handy during dayto-day interaction with faculty and students to help our campuses manage change and achieve an information sharing environment that benefits everyone.

Opportune moments to discuss scholarly communication issues come up in a variety of settings. Librarians can often take advantage of these opportunities to increase awareness of scholarly communication issues and new developments in scholarly publishing. Discussions may then result in a faculty member's use of, and support for, new services created by the library's scholarly communication initiatives. Some faculty may even become advocates for introducing changes in the institution's strategies of disseminating research results.

The ACRL Scholarly Communication Toolkit ${ }^{1}$ includes a wide range of information and resources to help you understand these issues and support your work on campus. The following real life questions present promising openings for you to take the information from the toolkit and other online resources to educate library users and create change on your campus.

\section{Case 1: Limited journal access}

Professor Jameson was trying to get online access to a journal article for her research through the library, but the library did not provide access to it. So, she asked her subject librarian why.

\section{Opportunity}

The librarian could take the chance to talk about the access barrier created by the spiraling costs of journal subscriptions. She could also bring up the concept of open access and the publication of open access peer-reviewed journals. That would inform Jameson of the pricing practices of journal publishers $^{2}$ and new scholarly publishing models ${ }^{3}$ that promote greater access at lower costs to readers.

This same discussion could follow questions surrounding journal cancellation activities necessitated by the recent economic climate. It would also be a prime opportunity to discuss what academic authors, editors,

Adrian K. Ho is scholarly communication librarian at Western Libraries of the University of Western Ontario, e-mail: aho88@uwo.ca; Daniel R. Lee is director of the office of copyright management and scholarly communication at the University of Arizona, e-mail: leed@email.arizona.edu

๑ 2010 Adrian K. Ho and Daniel R. Lee 
and reviewers can do to initiate change. ${ }^{4}$ For instance, authors can keep an eye on the pricing policies of journals in their fields and, where possible, choose to submit manuscripts to high-quality journals that have reasonable pricing practices. Faculty who serve as editors and reviewers of a subscription-based journal can examine the journal's pricing practices and start an inhouse discussion on pricing if appropriate.

\section{Case 2: Efficient dissemination of research updates}

Professor Tremblay and his colleagues recently founded a new research center on nanotechnology. To draw attention to their new effort, they are looking for a reliable channel to publish and disseminate updates of their research activities and findings efficiently.

\section{Opportunity}

The library can offer open access online publishing services ${ }^{5}$ to the research center if the library hosts its own publishing platform or participates in a consortial or collaborative online publishing initiative. Such services will relieve researchers of worrying about access and maintenance issues, support their need to disseminate and preserve research outcomes, and at the same time introduce them to an alternative scholarly publishing avenue that promises

\section{ACRL OnPoint chat: Conversational openings with faculty about scholarly communication}

Share your strategies to promoting scholarly communication and ask colleagues for advice during the free March ACRL OnPoint chat, convened by the authors of this month's scholarly communication article. Join Adrian Ho and Dan Lee on Thursday, March 4, 2010, at 1 p.m. Central to get and share tips on talking with your faculty. Complete details and login information are available on the ACRL Web site at www.ala. org/ala/mgrps/divs/acrl/events/onpoint/. to reach a broad readership in a cost-effective manner.

Library publishing services can cover a variety of campus-based scholarly publications, such as peer-reviewed journals, faculty monographs, and technical reports. These services illuminate the library's changing role in the scholarly communication process ${ }^{6}$ and reinforce the library's status as a crucial partner in supporting learning and advancing scholarship.

\section{Case 3: Student research reports}

Professor Schulz teaches journalism at the graduate level. Her students have to conduct independent studies and write reports based on their investigations. She wants to make the students' reports widely available in order to highlight the value of student journalism, so she asks the librarian for ideas.

\section{Opportunity}

This is a great opportunity to call attention to open access digital repository services, both institutional and disciplinary. ${ }^{7}$ Local or shared repositories provide dissemination and preservation services that enhance the visibility and accessibility of the institution's intellectual output. They also advance scholarship by expediting communication between different academic communities. Different types of digital repositories around the world can be found by using the Directory of Open Access Repositories ${ }^{8}$ and the Registry of Open Access Repositories.?

As in Case 2, digital repositories can serve as hosts for a range of material types. These could include, but aren't limited to, electronic theses and dissertations, student publications, survey and other data, photographic and manuscript archives, and previously published scholarly articles.

Before depositing previously published journal articles in a digital repository, authors should check resources, such as RoMEO ${ }^{10}$ from the University of Nottingham, to confirm that posting the articles online will not violate the copyright policies of the journal publishers concerned. 
For scholarly works yet to be published, authors and creators should retain the appropriate rights ${ }^{11}$ that will allow them to post their works in digital repositories. This issue highlights for authors, students, and faculty the benefits copyright holders can gain by managing their own publishing rights, enabling them to achieve the level of access they desire.

\section{Case 4: Dissertation copyright}

Michele Jackson is preparing to submit her dissertation and calls you to say she is confused by the option of paying an additional fee to have her copyright registered.

\section{Opportunity}

Now is a good time to explain some of the facts of copyright law, including the lack of a requirement to register a work for protection, as well as the additional value registration can bring. It is also an opportunity to explain the importance of authors holding on to their copyrights ${ }^{12}$ in order to control the ways readers can find and use their works.

If Jackson had previously published any of her dissertation chapters as journal articles, this issue becomes an even greater concern. If she had retained the relevant rights when she signed her journal publishing agreements, she would have the necessary control over her own works to include them in this and any future works.

Seemingly simple questions like this can often lead to broader topics. This technical question could also lead to a discussion of new models ${ }^{13}$ for publication of her dissertation and in her future career that take advantage of her rights as an author.

\section{Case 5: National Institutes of Health's (NIH) Public Access Policy}

Professor Wilson from Biochemistry called saying he just heard from NIH that his recent grant report didn't comply with their Public Access Policy. They said he needed to include the PubMed Central ID Number for the articles he published as a result of the research his lab conducted under the grant. He asked if you could help him find the number and explain what this new bureaucracy was all about anyway.

\section{Opportunity}

Working with researchers trying to comply with the NIH Public Access Policy gives librarians an opportunity to address a number of important issues. One natural starting point is to address the availability of government-funded research findings to a wide readership, including taxpayers, health professionals, and other researchers. ${ }^{14}$ Broad readership increases impact. ${ }^{15}$ This conversation could also lead to a discussion of the common practice of journal publishers to require authors to transfer copyright of their articles.

To make their articles available in PubMed Central, authors need to be sure they retain rights that allow for deposit. Some publisher policies provide for this by default, and some even make the deposit to PubMed on behalf of their authors. ${ }^{16}$ For others, authors can attach formal addenda ${ }^{17}$ to journal publishing agreements in order to retain the rights to reuse the articles and post them online.

\section{Case 6: Open educational resources}

Dr. Akedoreva is a visiting scholar from a developing country. She is compiling a list of educational materials that are freely available online so that she can access and adapt them for local noncommercial use when she returns to her home country in three months. She plans to share the list with other educators there so that they all can benefit.

\section{Opportunity}

Akedoreva would be pleased to learn about open educational resources (OER) ${ }^{18}$ and OER collections such as MIT OpenCourseWare, ${ }^{19}$ MERLOT, ${ }^{20}$ and Connexions. ${ }^{21}$ These collections provide materials for teaching and learning that are openly available for re-use and, often, adaption to users' local, specific needs. 
There is also DiscoverEd, ${ }^{22}$ a search engine for OER. Promoting these sites will drive home the benefits of open access and help avoid duplicating educators' efforts to create educational materials. A Creative Commons license $\mathrm{e}^{23}$ is sometimes appended to OER to explicitly specify the terms and conditions under which reuse and customization of the resources are allowed by the copyright owner. Akedoreva should be shown how to look for these licenses so that she will not infringe on the resource creator's copyright.

\section{Case 7: Monograph purchases}

Professor Balin, chair of the English Department, has recently returned from a professional conference where he heard several conversations about diminishing sales of scholarly monographs. He is concerned about how this may impact the junior faculty in his department and the difficulties this could cause for their tenure cases. He called to ask about the library's role in this trend.

\section{Opportunity}

Such a call opens a window into a wideranging conversation about the current state of scholarly publishing. It could start with a discussion of financial pressures on libraries brought about by years of flat or nearly flat collections budgets while journal prices have escalated steadily year after year. ${ }^{24}$ This has led many libraries to respond by cutting back on book purchases, including purchases specifically from university presses.

But the conversation needn't stop there. This is an excellent opportunity to talk about the emergence of new publishing models ${ }^{25}$ and how they can generate positive change in scholarly communication. For instance, open access publishing has been adopted by Open Humanities Press ${ }^{26}$ and Athabasca University Press ${ }^{27}$ to broaden the dissemination of their peer-reviewed monographs and to enhance knowledge sharing. Meanwhile, library-press partnership initiatives, ${ }^{28}$ such as University of California Publishing Services, ${ }^{29}$ the University of Michigan's digitalculturebooks, ${ }^{30}$ and Pennsylvania State University's
Romance Studies series, ${ }^{31}$ demonstrate how different stakeholders in the scholarly communication process can collaborate to create a viable alternative avenue to traditional monograph publishing, where faculty can continue to share their research and scholarship with colleagues and other readers.

\section{Conclusion}

All of the cases discussed here are practical examples with suggested responses to openings given to you when faculty and student turn to their librarian for answers. But you can start your own conversations as well. Begin by asking your faculty and graduate students where they publish, how they raise the profile of their works, and what problems they are having in this realm. When they start telling you about their own experiences and what they would like to be different, you can help them reach their own scholarly publishing goals, working in the issues raised on the ACRL Scholarly Communication Toolkit.

More scenarios are available in the Toolkit. ${ }^{32}$ If you know other useful resources or wish to share your experience of promoting scholarly communication, please post a comment on the Toolkit.

\section{Notes}

1. ACRL Scholarly Communication Toolkit, acrl.ala.org/scholcomm/.

2. Journal Economics Toolkit section, www.acrl.ala.org/scholcomm/node/9.

3. Scholarship and Publishing Toolkit section, www.acrl.ala.org/scholcomm/node/7.

4. What You Can Do Toolkit section, www.acrl.ala.org/scholcomm/node/27.

5. Research Library Publishing Services, www.arl.org/bm doc/research-library -publishing-services.pdf.

6. ACRL Scholarly Communications 101 Starting With the Basics: Systems Overview, acrl.ala.org/media/video/intro_systems.mp4.

7. Digital Repositories Toolkit section, www.acrl.ala.org/scholcomm/node/19.

8. Directory of Open Access Repositories, www.opendoar.org/. 
9. Registry of Open Access Repositories, roar.eprints.org/.

10. RoMEO, www.sherpa.ac.uk/romeo/.

11. Authors Rights Toolkit section, www. acrl.ala.org/scholcomm/node/8.

12. Authors Rights Toolkit section, www. acrl.ala.org/scholcomm/node/8.

13. Scholarship \& Publication Toolkit section, www.acrl.ala.org/scholcomm/node/7.

14 Alliance for Taxpayer Access, www. taxpayeraccess.org/issues/access/index. shtml.

15. Open Citation Project, opcit.eprints. org/oacitation-biblio.html.

16. Information about Journals and the NIH Public Access Policy, publicaccess.nih. gov/submit_process_journals.htm.

17. Author Addenda Toolkit section, acrl. ala.org/scholcomm/node/41.

18. The Transformative Potential of Open Educational Resources (OER), www.arl.org /sparc/meetings/ala09mw/.

19. MIT OpenCourseWare, ocw.mit.edu/.

20. MERLOT, www.merlot.org/.

21. Connexions, cnx.org/.

("Holocaust resources" continued from page 82) is focused on the interests of academics, but others can participate, as well. Approximately 1,300 people subscribe to this list. Subscribe: LISTSERV@H-NET.MSU.EDU.

- USHMM-T. This is the U.S. Holocaust Memorial Museum's discussion list for Holocaust teachers. There are more than 250 subscribers to this list. Subscribe: USHMMT@LISTSERV.USHMM.ORG

\section{Electronic journals}

\section{- Studies in Christian-Jewish Rela-}

tions. Published by the Center for ChristianJewish Learning at Boston College, this journal addresses historical and contemporary issues related to the relationships between members of these two religious groups. While not focused specifically on the Holocaust, issues regarding it and the broader subject of anti-Semitism appear frequently in its articles. Access: http://escholarship. bc.edu/scjr.
22. DiscoverEd, discovered.creativecommons.org/search/.

23. Creative Commons licenses, creativecommons.org/about/licenses/.

24. Journal Economics Toolkit section, www.acrl.ala.org/scholcomm/node/9.

25. Scholarship and Publishing Toolkit section, www.acrl.ala.org/scholcomm/ node $/ 7$.

26. Open Humanities Press, www. openhumanitiespress.org/.

27. Athabasca University Press, www. aupress.ca/.

28. The Campus-based Publishing Resource Center, www.arl.org/sparc/partnering/.

29. University of California Publishing Services, www.ucpress.edu /pubservices/.

30. digitalculturebooks, www.digitalculture.org/.

31. Penn State Romance Studies, romancestudies.psu.edu.

32. What You Can Do: Conversational Openings section, www.acrlala.org /scholcomm/node/43. n

\begin{abstract}
- War Crimes, Genocide and Crimes against Humanity. This journal is "a multidisciplinary, peer-reviewed scholarly journal dedicated to understanding the conceptualization, etiology, and prevention of violations of international criminal and humanitarian law." Access: http://www. war-crimes.org.
\end{abstract}

\section{Conclusion}

The topic of the Holocaust is difficult to grasp in its entirety, because its impact has been so wide-ranging. However, the sites displaying in this article provide the reader with guidance and direction.

For those focusing on very specific information, queries on discussion lists mentioned above might be of particular help.

Taken as a whole, however, researching on the Holocaust makes for a fascinating and enlightening journey. 